\title{
DYNORPHIN REDUCES CALCIUM-DEPENDENT ACTION POTENTIAL DURATION BY DECREASING VOLTAGE-DEPENDENT CALCIUM CONDUCTANCE
}

\author{
MARY ANN WERZ and ROBERT L. MACDONALD* \\ Department of Neurology, University of Michigan, 1103 East Huron, Ann Arbor, MI 48109 (U.S.A.) \\ (Received November 15th, 1983; Revised version received January 30th, 1984; Accepted February 7th, \\ 1984)
}

Key words: opioid peptide actions - opioid receptors - dynorphin - voltage-dependent calcium conductance - sensory ganglion neuron

The opioid peptide dynorphin decreased somatic calcium-dependent action potential duration in a portion of mouse dorsal root ganglion (DRG) neurons without altering resting membrane potential or conductance. Dynorphin action was antagonized by naloxone. Responses of DRG neurons to dynorphin differed from responses to the opioid peptides leucine-enkephalin, which binds preferentially to deltaopiate receptors, and morphiceptin, which binds preferentially to mu-opiate receptors. Firstly, many DRG neurons responded to dynorphin but not to leucine-enkephalin or morphiceptin. Secondly, dynorphin responses, unlike leucine-enkephalin or morphiceptin responses, persisted following intracellular injection of cesium, a potassium channel blocker. We suggest that dynorphin acts at an opiate receptor distinct from mu- and delta-receptors and that this receptor is coupled to a voltage-dependent calcium channel.

Previously we reported that both mu- and delta-opiate receptors are present on the somata of some dorsal root ganglion (DRG) neurons in cell culture, that there is a heterogeneous distribution of these receptors among DRG neurons, and that binding of opiates to both receptor types decreases the duration of DRG somatic calcium-dependent action potentials [13-15]. Additionally, we have suggested that both mu- and delta-opiate receptors are coupled to potassium channels and that binding of opioids to these receptors results in an augmentation of a potassium conductance [16]. The purpose of the present investigation was to compare the actions of the opioid peptide dynorphin, which may preferentially bind to kappa-receptors $[2,3,7,9]$, with the action of morphiceptin [1], a mu-receptor selective ligand, and leucine-enkephalin, a delta-receptor preferring ligand [4]. Our data suggest that dynorphin decreases calcium-dependent action potential duration but that it acts at a receptor distinct from mu- and delta-receptors.

Preparation of mouse spinal cord and DRG co-cultures and electrophysiological techniques were as previously described [10]. Recording medium was a Tris- $\mathrm{HCl}$

\footnotetext{
${ }^{*}$ Author for correspondence.
} 
buffered ( $\mathrm{pH} \mathrm{7.2-7.4)} \mathrm{balanced} \mathrm{saline} \mathrm{(} 320 \mathrm{mOsm}$ ) containing (in $\mathrm{mM}$ ): $\mathrm{NaCl}, 137$; $\mathrm{KCl}, 5.3 ; \mathrm{MgCl}_{2}, 0.8 ; \mathrm{CaCl}_{2}, 5.0$; Tris-base, 13 ; glucose, 5.6, and tetraethylammonium (TEA), 5.0. DRG neurons were impaled with either $4 \mathrm{M}$ potassium acetate (KAc)- or $4 \mathrm{M}$ cesium acetate (CsAc)-filled micropipettes (20-40 M $)$ and somatic calcium-dependent action potentials were evoked by brief (100-500 $\mu \mathrm{sec})$ depolarizing current pulses at a frequency of 4 per min. Dynorphin 1-17 $_{\text {(Peninsula), mor- }}$ phiceptin (Peninsula) and leucine-enkephalin (Peninsula) were applied to single neurons by pressure ejection (0.5-2.0 psi) from micropipettes with tip diameters of 2-5 $\mu \mathrm{m}$. Application was for $1 \mathrm{sec}$ delivered $4 \mathrm{sec}$ prior to evoking an action potential. Naloxone (Endo Laboratories) was applied by diffusion from 15-25 $\mu \mathrm{m}$ diameter micropipettes positioned approximately 10-15 $\mu \mathrm{m}$ from the DRG neuron.

During recording with KAc-filled micropipettes, action potentials were evoked from resting membrane potential $(-45$ to $-70 \mathrm{mV}$ ) and typically had durations between 7 and $20 \mathrm{msec}$. In neurons impaled with CsAc-filled micropipettes, resting membrane potential, action potential duration and action potential afterhyperpolarization initially corresponded to those observed with KAc recordings. Over 1-15 min, resting membrane potential was reduced to 0 to $-20 \mathrm{mV}$, action potential duration was prolonged to $100-1500 \mathrm{msec}$ and the after-hyperpolarization was abolished, consistent with substantial blockade of potassium conductance by intracellular cesium [11]. Holding current was applied to maintain baseline membrane potential at about $-60 \mathrm{mV}$. Opioid peptide action was often initially assessed on DRG neuron calcium-dependent action potentials during recording with KAc-filled micropipettes and then re-assessed following reimpalement of neurons with CsAcfilled recording micropipettes.

A $1 \mathrm{sec}$ application of dynorphin at $1 \mu \mathrm{M}$ delivered 3-4 sec prior to evoking an action potential decreased the calcium component of action potentials in 47 of 86 DRG neurons (55\%) (Fig. 1A) but did not affect action potential duration or con-

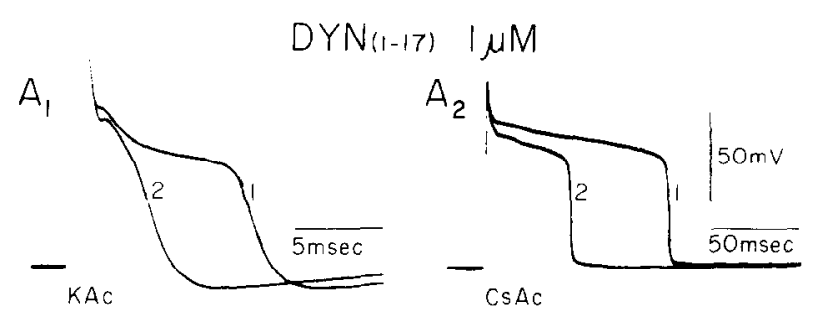

Fig. 1. Dynorphin decreased the duration and amplitude of the calcium component of DRG neuron somatic action potentials. In this and all subsequent figures, action potentials were evoked at a frequency of 4 per min by $100 \mu \mathrm{sec}$ depolarizing current pulses. Action potentials evoked prior to (1) and subsequent to (2) opioid peptide application were superimposed. $\mathrm{A}_{1}$ : pressure application of $1 \mu \mathrm{M}$ dynorphin $\mathrm{n}_{1-17}$ (DYN) for $1 \mathrm{sec}$ and delivered $4 \mathrm{sec}$ prior to evoking an action potential decreased the duration and amplitude of the calcium-dependent action potential during recording with a KAc-filled micropipette. $\mathrm{A}_{2}$ : the KAc-filled micropipette was withdrawn and the neuron was reimpaled with a $C$ sAc-filled micropipette. The DRG neuron response to dynorphin persisted following intracellular injection of cesium. 
figuration in the remaining $45 \%$ of neurons. The portion of DRG neurons that responded to dynorphin appeared to vary as a function of culture dissection. Of the neurons that responded to dynorphin, the magnitude of the effect, measured from the onset of the depolarizing stimulus to the point where potential during repolarization intersected with resting potential, varied considerably across neurons, with effects produced by $1 \mu \mathrm{M}$ dynorphin ranging from 9 to $89 \%$ with a mean reduction of $32 \%$. Dynorphin action was dose-dependent over a concentration range of $10 \mathrm{nM}$ to $1 \mu \mathrm{M}$. In DRG neurons that had responded to dynorphin during recording with KAc-filled micropipettes, the response to the opioid peptide persisted after subsequent reimpalement and intracellular injection of cesium (10 of 11 neurons) (Fig. 1B). The mean reduction of calcium-dependent action potential duration produced by dynorphin in these 10 neurons during recording with KAc- and CsAc-filled micropipettes was $45 \%$ and $49 \%$, respectively.

We compared the actions of dynorphin $(1 \mu \mathrm{M})$ to morphiceptin and leucineenkephalin $(10$ or $20 \mu \mathrm{M})$ on single DRG neurons $(n=46)$ during recording with KAc-filled micropipettes. The order of opioid peptide application was varied and did not affect the results. Of these neurons, 25 did not respond to any of the opioid peptides, and the majority of the remainder responded only to dynorphin $(n=16)$. Only 4 neurons responded to all 3 opioid peptides, and one DRG neuron responded to leucine-enkephalin but not dynorphin (morphiceptin was not tested on this neuron).

We compared the actions of dynorphin, morphiceptin, and leucine-enkephalin on single DRG neurons recorded initially with KAc-filled miropipettes and subsequently with CsAc-filled micropipettes. During KAc recording, some DRG neurons responded only to dynorphin but not leucine-enkephalin or morphiceptin $(n=6)$ (Fig. 2A), while others responded to dynorphin as well as morphiceptin and/or leucine-enkephalin $(n=5)$ (Fig. 2B). In all cases but one, dynorphin responses persisted following intracellular cesium injection while responses to leucine-enkephalin and morphiceptin were abolished (Fig. 2A $\mathrm{A}_{2}, 2 \mathrm{~B}_{2}$ ). The one DRG neuron in which dynorphin responses were abolished by intracellular cesium injection had also responded to leucinc-enkephalin and morphiceptin during KAc recording. The responses of this neuron to leucine-enkephalin and morphiceptin were also abolished by intracellular cesium injection.

We previously reported that leucine-enkephalin and morphiceptin responses were antagonized by naloxone [13-15]. Dynorphin-mediated decreases of action potential duration were tested for sensitivity to naloxone antagonism. The paradigm followed was to obtain a control response to a $1 \mathrm{sec}$ application of dynorphin. Then a $1 \mu \mathrm{M}$ naloxone-containing micropipette was positioned near the DRG neuron which allowed the antagonist to diffuse into the medium surrounding the cell after which dynorphin was re-applied. Finally, the naloxone-containing micropipette was removed from its position near the neuron, and dynorphin was re-applied. Naloxone reversibly antagonized decreases in calcium-dependent action potentials produced by dynorphin $(\mathrm{n}=8)$ (Fig. 3). 

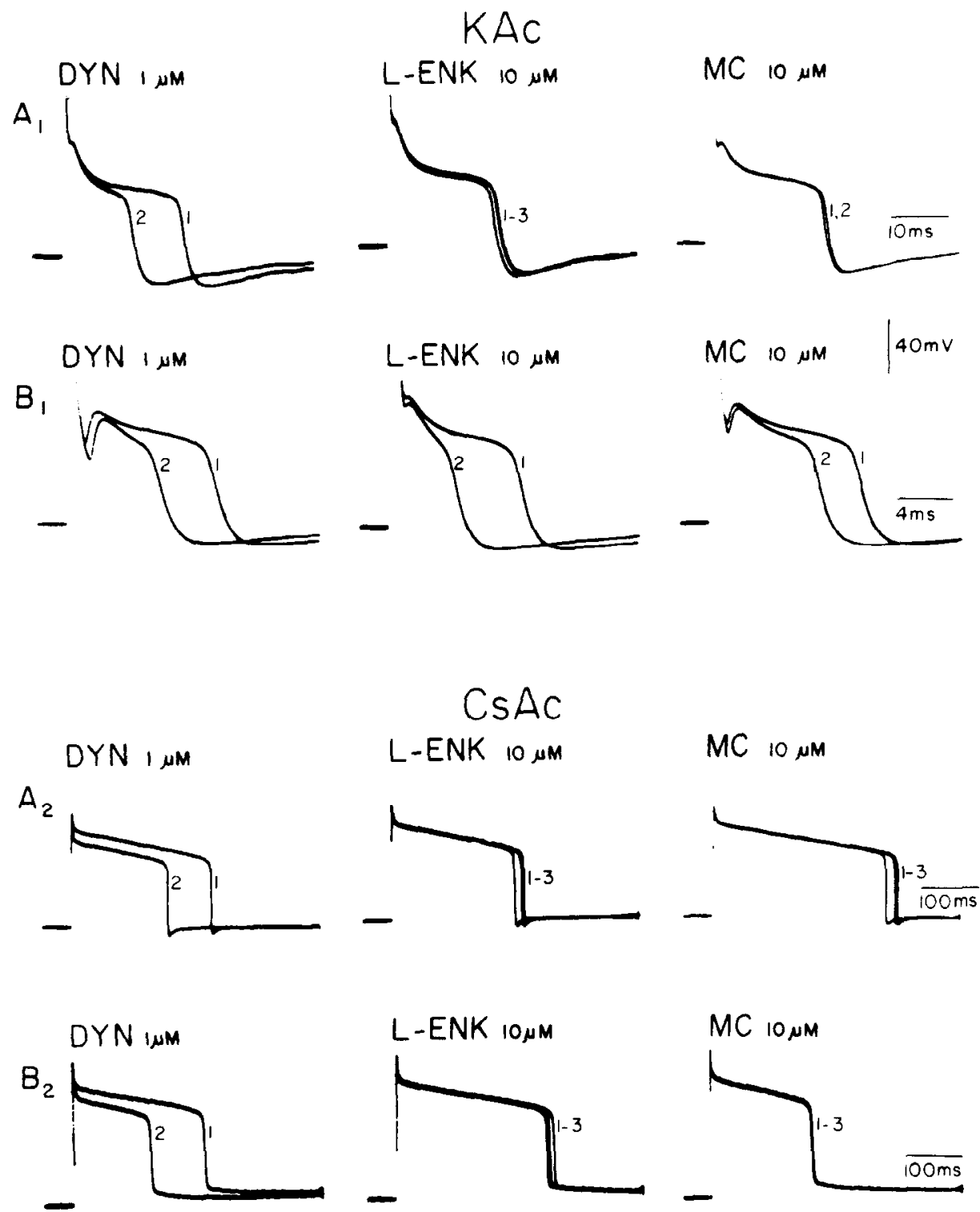

Fig. 2. DRG neuron responses to dynorphin, leucine-enkephalin and morphiceptin were heterogeneous. $A$ and $B:$ a DRG neuron that responded well to dynorphin but not leucine-enkephalin (L-ENK) or morphiceptin $(M C)\left(A_{1}\right)$ and a DRG neuron that responded to all 3 of the opioid peptides $\left(B_{1}\right)$ during recording with KAc-filled micropipettes. Subsequent reimpalement of the neurons with a CsAc-filled micropipette and intracellular injection of cesium did not attenuate neuronal responses to dynorphin in either case $\left(A_{2}, B_{2}\right)$. $B_{2}$ : although dynorphin responses persisted following intracellular iontophoresis of cesium, leucine-enkephalin and morphiceptin responses were blocked. 
We observed many DRG neurons that responded to dynorphin but not to morphiceptin or leucine-enkephalin. Furthermore, dynorphin responses, in contrast to leucine-enkephalin or morphiceptin responses (see also ref. 16), were not blocked by intracellular injection of the potassium channel blocker cesium. Based on these data, we suggest that on DRG neuron somata dynorphin acts at a receptor distinct from mu- and delta-receptors. Based on rank order of potency, cross-tolerance and selective protection paradigms in the peripheral nervous system $[2,3,7,18]$ and binding studies in the central nervous system [3, 9], dynorphin has been proposed as an opioid peptide with high affinity for kappa-receptors. Recently a high incidence of kappa-binding sites has been reported in spinal cord [12] and intrathecal injection of kappa agonists has produced analgesia [8, 17]. Thus, the dynorphin specific responses we observed on DRG neurons may be mediated by kappa-opiate receptors. Therefore, we suggest that dynorphin(kappa)-receptors as well as muand delta-receptors are present on DRG neuron somata. Furthermore, it appears that the distribution of opiate receptors among DRG neurons is variable. Of the DRG neurons with somatic opiate receptors, our results suggest that the largest portion have dynorphin-receptors and a minority of these also have mu- and/or deltaopiate receptors.

The action of mu-, delta- and dynorphin-receptors is to decrease calcium entry into DRG neurons. A similar action of opiates at synaptic terminals of DRG neurons would result in a decrease of neurotransmitter release [5, 6]. However, dynorphin receptors decrease calcium-dependent action potential duration, and hence calcium entry, by a mechanism different from mu- and delta-receptors. Dynorphin receptors appear to be coupled to voltage-dependent calcium channels while mu- and delta-receptors may be coupled to voltage- and/or calcium-dependent potassium channels. Interestingly, simultaneous activation on the same synaptic ter-
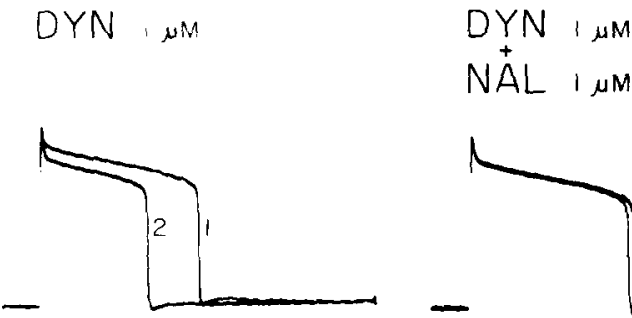

DYN I $\mu M$
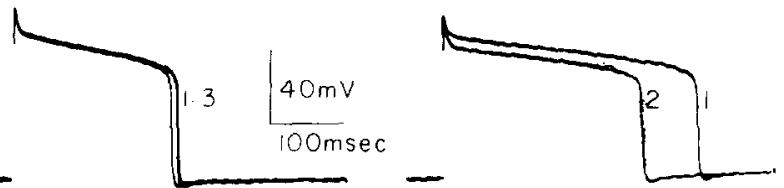

Fig. 3. Naloxone antagonized dynorphin-induced decreases of DRG neuron somatic calcium-dependent action potential duration. Action potential duration was decreased following application of dynorphin. When action potential duration had returned to baseline, a micropipette with tip diameter of $20 \mu \mathrm{m}$ and containing $1 \mu \mathrm{M}$ naloxone (NAL) was positioned to within $20 \mu \mathrm{m}$ of the neuron. After naloxone was permitted to diffuse from the micropipette for $1 \mathrm{~min}$, application of dynorphin did not affect action potential duration. Following removal of the $1 \mu \mathrm{M}$ naloxone-containing micropipette from its position near the cell, dynorphin application again decreased the duration of the calcium component of the action potential. The recording micropipette contained $4 \mathrm{M}$ CsAc. 
minal of dynorphin-receptors with either mu- or delta-receptors might be additive and thus produce a maximal decrease of calcium entry and neurotransmitter release.

The authors thank Ms. Michaela Weeks for secretarial assistance. We thank Dr. Gordon Guroff for kindly supplying us with NGF. M.A.W. was supported by DA 5244. R.L.M. was supported in part by NIH Research Career Development Award NS 00480. The research was supported by NSF Grant BNS 81-18762.

1 Chang, K.J., Killian, K., Hazum, E., Cuatrecasas, P. and Chang, J.K., Morphiceptin (NH4-Tyr-ProPhe-Pro-CONH${ }_{2}$ ): a potent and specific agonist for morphine $(\mu)$ receptors, Science, 212 (1981) 75-77.

2 Chavkin, C., James, I.F. and Goldstein, A., Dynorphin is a specific endogenous ligand of the $x$ opioid receptor, Science, 215 (1982) 413-415.

3 Corbett, A.D., Paterson, S.J., McKnight, A.T., Magnan, J. and Kostelitz, H.W., Dynorphin ${ }_{1-8}$ and dynorphin $_{1-9}$ are ligands for the $\varkappa$-subtype of opiate receptor, Nature (Lond.), 299 (1982) 79-81.

4 Kosterlitz, H.W., Lord, J.A.H., Paterson, S.J. and Waterfield, A.A., Effects of changes in the structure of enkephalins and of narcotic analgesic drugs on their interactions with $\mu$ - and $\delta$-receptors, Brit. J. Pharmacol., 68 (1980) 333-342.

5 Macdonald, R.L. and Nelson, P.G., Specific-opiate-induced depression of transmitter release from dorsal root ganglion cells in culture, Science, 199 (1978) 1449-1451.

6 Mudge, A.W., Leeman, E.E. and Fischbach, G.D., Enkephalin inhibits release of substance P from sensory neurons in culture and decreases action potential duration. Proc. nat. Acad. Sci., U.S.A., 76 (1979) 526-530.

7 Oka, T., Negishi, K., Suda, M., Sawa, A., Fujino, M. and Wakimasu, M., Evidence that dynorphin-(1-13) acts as an agonist on opioid $x$-receptors, Europ. J. Pharmacol., 77 (1982) 137-141.

8 Piercey, M.F., Lahti, R.A., Schroeder, L.A., Einspahr, F.J. and Barsuhn, C., U-50.488 H, a pure kappa receptor agonist with spinal analgesic loci in the mouse, Life Sci., 31 (1982) 1197-1200.

9 Pfeiffer, A., Pasi, A., Mehraein, P. and Herz, A., A subclassification of $x$-sites in human brain by use of dynorphin 1-17, Neuropeptides, 2 (1981) 89-97.

10 Ransom, B.R., Christian, C.N., Bullock, P.N. and Nelson, P.G., Mouse spinal cord in cell culture. II. Synaptic activity and circuit behavior, J. Neurophysiol., 40 (1977) 1151-1162.

11 Tillotson, D. and Horn, R., Inactivation without facilitation of calcium conductance in caesiumloaded neurones of Aplysia, Nature (Lond.), 273 (1978) 312-314.

12 Traynor, J.R., Kelly, P.D. and Rance, M.J., Multiple opiate binding sites in rat spinal cord, Life Sci., 31 (1982) 1377-1380.

13 Werz, M.A. and Macdonald, R.L. Opioid peptides decrease calcium-dependent action potentials duration of mouse dorsal root ganglion neurons in cell culture, Brain Res., 239 (1982) 315-321.

14 Werz, M.A. and Macdonald, R.L., Heterogeneous sensitivity of cultured dorsal root ganglion neurones to opioid peptides selective for $\mu$ - and $\delta$-opiate receptors, Nature (Lond.), 299 (1982) 730-733.

15 Werz, M.A. and Macdonald, R.L., Opioid peptides with differential affinity for mu- and deltareceptors decrease sensory neuron calcium-dependent action potentials, J. Pharmacol. exp. Ther., 227 (1983) 394-402.

16 Werz, M.A. and Macdonald, R.L., Opioid peptides selective for mu- and delta-opiate receptors reduce calcium-dependent action potential duration by increasing potassium conductance, Neurosci. Lett., 42 (1983) 173-178.

17 Wood, P.L., Rackham, A. and Richard, J., Spinal analgesia: comparison of the mu agonist morphine and the kappa agonist ethylketazocine, Life Sci., (1981) 2119-2125.

18 Wüster, M., Schulz, R. and Herz, A., Opiate activity and receptor selectivity of dynorphin $1-13$ and related peptides, Neurosci. Lett., 20 (1980) 79-83. 